\title{
A Comparative Study of Waqf Legal System Between Indonesia and Malaysia
}

\author{
Islamiyati, ${ }^{1}$ Dewi Hendrawati, ${ }^{2}$ Aisyah Ayu Musyafah ${ }^{3}$ \\ \{islamiyati@yahoo.co.id ${ }^{1}$, dewihendrawati@lecturer.undip.ac.id ${ }^{2}$, aisyahayumusyafah@gmail.com ${ }^{3}$ \}
}

Law Faculty at Universitas Diponegoro, Semarang, Indonesia ${ }^{1}$, Law Faculty at Universitas Diponegoro, Semarang, Indonesia ${ }^{2}$, Law Faculty at Universitas Diponegoro, Semarang, Indonesia ${ }^{3}$

\begin{abstract}
Indonesia and Malaysia, were developing countries, the correlation of them was waqf law that had similarities and differences, from its implementation, legal basis, system, as well as the settlement of waqf disputes. This study analyzed the similarities and differences between Indonesia's waqf legal system and Malaysia's waqf legal system. Its benefit was in expanding the legal discourse on waqf at international level. The type of this research was library research that used comparative juridical approach, its data analysis method was comparative study. The research results explained that the implementation of waqf law between Indonesia and Malaysia, had their own characteristics that were adjusted to the typology of the community. The form of government of Indonesia and Malaysia were different, therefore its legal system was also different. The similarity of these two countries were the Islamic legal framework of non-absolute Shafi' I mazhab. However, in Malaysia, it was only implemented in certain states.
\end{abstract}

Keywords: Comparative, Legal System, Waqf, Malaysia, Indonesia

\section{Introduction}

Waqf is a legal act of wakif to separate and or give some of his assets to be used forever or in a certain term based on its interests for the need of worship and/or general welfare according to sharia (Islamic law). Throughout Islamic history, waqf had important role in improving Muslims' welfare. In the beginning, waqf law had emerged since the Prophet Muhammad SAW asked Umar Bin Khatab to give his assets by holding his principal assets (called as waqf asset) and to give the proceeds of the principal assets. Then the Prophet also asked to not sell, inherit and donate waqf assets, because of its benefit in community [1]. Therefore, at that time, waqf law principle had emerged, that was giving the assets by maintaining the waqf assets forever, and this principle was the basis of the enactment of waqf law. Furthermore, the practice of waqf was followed up by the generation of the Prophet's friends to the generation of Daulah Bani Umayyah and Abbasiah, then the generation of Turkey's Empire of Utsmani [1].

The development of waqf law was very rapid, besides Saudi Arabia, also spreading throughout the whole world, especially Islamic countries, for example; Turkey, Egypt, Iran, Pakistan, Malaysia, Bahrain, Bangladesh, Indonesia and others. This is because waqf was widely used in a large scope that could reach the interest of community generally, for example; to finance the education and research sector, provision of scholarship, construction of library building to study science and technology[2]. 
The development of waqf had advanced in Iran in the century of X AD, at that time waqf had expanded to the sectors of infrastructure, tourism, health service, education, hospital, and lodging.[2] In Turkey, in 1924, waqf condition had been showed from $75 \%$ of agricultural land was waqf land, and then it was rented by the community using profit sharing system. Likewise, in AlJazair (50\%), Tunisia (33\%), Egypt (12,5\%). In Kuwait, waqf institution had been established to administer waqf assets and manage it in a professional manner, that provided benefit aspect for orphans and children with disabilities, household harmony and gave reward to scientific work[3].

In Indonesia, waqf had become a law whose implementing regulation had been determined by the state without ignoring religious law. Religious rules had correlation with waqf thoroughly, while state regulation had correlation with detailed information regarding management, use, and legal protection of its waqf, so that the involved parties in waqf law was protected by law. As the result, there was a harmonization between state law and religious law, because the goals and benefits of waqf assets had highly important role in national development goals such as; educate nation's life and maintain general welfare.

In Malaysia, waqf's benefit had been in large scope, besides the aspect of worship, also in business and commerce world, banking, insurance, also industry and tourism [3]. If it was compared with Indonesia, although both of the countries had status as developing countries and their location was next to each other, waqf law had highly significant similarities and differences, from its implementation, legal basis, system, and the dispute settlement of waqf.

Based on the explanation above, the similarities and differences (comparative study) between Indonesia's waqf legal system and Malaysia's waqf legal system needed to be explained. The main reason was because Indonesia and Malaysia has similarities in their location that were located in the Southeast Asian and they were Malays descent, and historically had strong relations from the aspects of language, race, religion and the establishment of their countries. Moreover, both of the countries also had different form and system of their government, where their waqf law was also different. Through the analysis and identification of the comparison of waqf law between Indonesia and Malaysia, therefore it will be useful as evaluation of waqf law policy and the development of waqf strategic role that was implemented in Indonesia.

\section{Methods}

The type of this research was library research, whose data source used secondary data, that was obtained from literature studies related to the research theme, that was waqf legal system in Malaysia and Indonesia. The research approach method used normative juridical, related to the law that had been described in legislation. The data analysis used a comparative study, that was comparing and analyzing waqf legal system between Indonesia and Malaysia to answer research problems. The research tradition was qualitative research that aimed to develop a theoretical concept based on reading material. Data processing was carried out by reviewing, organizing, or compiling data, synthesizing, analyzing, editing, and concluding. 


\section{Discussion and Analysis}

In this discussion, waqf legal system in Indonesia would be explained first, it consisted of some elements, that were; the enactment history, legal basis, legal framework, mazhab (school of thought) adopted in the implementation of waqf, nazhir coordinator, use of waqf assets, waqf implementation practices, and waqf dispute settlement institutions. After that, waqf legal system in Malaysia was also explained such as the elements above, then a comparison of the similarities and differences of waqf legal was analyzed.

\subsection{Waqf Legal System in Indonesia}

In Indonesia, waqf had emerged along with the emergence of Islam in Indonesia in XIII century $\mathrm{AD}$, at that time Indonesia was still in the form of kingdoms. However, the actual implementation of waqf practice in community had developed since XV century AD [4]. At that time the practice of waqf was in the form of a place of worship (mushalla, mosque, surau), a place to study Islam (Islamic education and boarding schools), a place for joint activities in the community (farming, gardening, building public facilities[2].

The teachings of waqf by Muslims could be used as a daily worship activity in addition to other life activities. At that time, the law of waqf in Indonesia was included as legal realism, that was real law and a living law because it was practiced in community, its legal basis was from the principles or values contained in religious teachings (Islam). Along with the rapid development of waqf, waqf had become a law whose implementation was based on the laws stipulated by the state.

Indonesian recognized and protected waqf actions committed by the Indonesian people, because the benefits of waqf assets[5] could assist the government in achieving national development goals as stated in the Preamble of the 1945 Constitution of the Republic of Indonesia Paragraph IV. Besides as an effort to fulfill the constitutional rights of citizens to worship in accordance with their beliefs and religions. Muslims (as well as members of other religions) had been protected by the state in carrying out their teachings including giving waqf, as explained in the First Line of Pancasila and the 1945 Constitution of the Republic of Indonesia Article 29 Paragraph (1) and (2).

Based on the explanation above, it could be understood that the enactment of waqf law in Indonesia used religious law (Islam) and state law. Religious law was based on Al-Qur'an and Al-Hadith [6] as well as the book of figh that usually used non-absolute Shafi'i mazhab (school of thought), it meant that it accepted the teachings of other legal mazhab (school of thought), such as Hanafi and Maliki mazhab (school of thought). The position of religious law was related to the validity of waqf, while state law was related to legal certainty to provide legal protection for the implementation of waqf including waqf assets. Thus state law provided reinforcement for the enactment of religious law, so that there was harmony (a harmonious and mutually supportive relationship) between state law and religious law.

The form of government recognition and protection whose relation to waqf law was the formulation of state policy to make laws and regulations that were used as a basis or juridical basis as well as a guideline for Muslims in giving waqf as well as legal certainty of waqf. The legislations were;

1. Act Number 5/1960 concerning Basic Regulations on Agrarian Principles. The most essential provision in this act was the protection of waqf lands[7].

2. Government Regulation Number 28/1977 concerning Donation of Land Ownership. 
3. Regulation Minister of Home Affairs Number 6/1977 concerning Land Registration Regarding Land Ownership Donation[7].

4. Regulation of Minister of Religion Number 1/1978, Joint Instruction between Minister of Religion and Minister of Home Affairs Number 1/1978, Decree of Minister of Religion Number 73/1978 concerning the Delegation of Authority to Provincial/Regional Office of Religion Department in Indonesia to hire/terminate each Head of Religious Affairs District Office as PPAIW (Officials Maker of the Waqf Pledge Deed)[8].

5. Regulation of Islamic Directorate General of Correctional Center Number Kep/D/75/1979 concerning Forms and Guidelines for Implementing the Regulations concerning Donation of Land Ownership[8].

6. Presidential Instruction Number 1/1991 concerning Compilation of Islamic Law (KHI) Book III concerning Waqf Law.

7. Act Number $7 / 1989$ jo Act Number 3/2006 concerning Religious Courts that stipulated the authority over legal issues of waqf to the Religious Courts, and aligns the Religious Court's position with other courts[9].

8. Act Number $41 / 2004$ that was enacted on October $27^{\text {th }}$, 2004 was the first act that specifically regulated waqf. with the enactment of this act, all waqf regulations were still valid as long as they did not conflict and/or had not been replaced by new regulations based on this act[10].

9. Presidential Regulation Number 28/1977, regarding the regulation that explained waqf.

In Indonesia, the implementation of waqf was under the authority of the Ministry of Religion for the Affairs of Zakat, Infaq, Shadaqah and Waqf (ZISWAF). Since 2004, since the enactment of the Waqf Law Number 41/2004, waqf affairs were under coordination between Ministry of Religion and Indonesian Waqf Institution (BWI). BWI had the authority to coordinate the management of waqf assets, then BWI collaborated with Nazhirs who were from elements of community, such as; BKM (Mosque Welfare Institution), institutions, foundations, or community organizations to manage waq assets according to community needs [11]. People who gave waqf through District Ulama Council that was called as Kantor Urusan Agama (Religious Affairs Office). Regulations regarding waqf law, besides state policies, were also in the hands of Indonesian Ulama Council in the form of fatwa, for example; Fatwa of Indonesian Council of Religious Scholars (MUI) regarding waqf in cash, intellectual property rights waqf (HKI), productive waqf, and others[11].

The legal basis for waqf stipulated by the government aimed to assist Muslims in carrying out legal action of waqf, including providing instructions for the settlement of waqf disputes so that problems, conflicts or disputes could be settled easily and significantly. Article 62 of Act number 41/2004 explained that the steps for settling waqf disputes were;

a. Waqf dispute settlement was settled through deliberation to reach consensus.

b. If the dispute settlement as stated in paragraph (1) was unsuccessful, the dispute could be settled through mediation, arbitration or court.

Institutions that had the authority to settle waqf disputes were:

a. The authority of administrative sanctions belonged to the Ministry of Religion

b. Criminal Sector was under the authority of the General Court

c. Civil Sector was the authority of Religious Courts

Based on the explanation above, it could be concluded through the following table : 
Tab 1. Waqf Law in Indonesia

\begin{tabular}{|c|c|}
\hline Waqf Law in Indonesia & Description \\
\hline The emergence history & $\begin{array}{l}\text { Along with the emergence of Islam in Indonesia, that was in the } \\
\text { XIII century AD. }\end{array}$ \\
\hline Legal Basis & $\begin{array}{l}\text { Al-Qur'an and Al-Hadith } \\
\text { Presidential Regulation Number } 28 / 1977 \text { concerning donation of } \\
\text { land ownership, Islamic Law Compilation of Presidential } \\
\text { Instruction Number 1/1991 Third Part concerns waqf law, Act } \\
\text { Number 41/2004 is concerning Waqf and Government Regulation } \\
\text { Number 42/2006 concerning Implementation of Government } \\
\text { Regulation Number 41/2004. }\end{array}$ \\
\hline $\begin{array}{l}\text { Legal Mazhab (Legal school of } \\
\text { thought) }\end{array}$ & $\begin{array}{l}\text { Non-absolute Shafi'I mazhab, it meant Shafi'i's view was used } \\
\text { more, but also accepted mazhab of Hanafi on waqf case that was } \\
\text { suitable to be implemented for Indonesian people, for example; } \\
\text { productive waqf, waqf in cash, and waqf exchange. }\end{array}$ \\
\hline Waqf Legal Frameu & Includino Islamic law that was enacted nationally \\
\hline Implementer of Waqf Pra & $\begin{array}{l}\text { It was under the coordination of the Ministry of Religion through } \\
\text { the District Ulama Council, that was called as Religious Affairs } \\
\text { Office. }\end{array}$ \\
\hline Nazhir Coordinator & $\begin{array}{l}\text { BWI collaborated with Nazhir who were from elements of } \\
\text { community, such as; BKM (Mosque Welfare Agency), } \\
\text { institutions, foundations, or community organizations, to manage } \\
\text { waqf assets according to community needs. }\end{array}$ \\
\hline Waqf Dispute Resolution & $\begin{array}{l}\text { Through deliberation, if it did not work through mediation, if it } \\
\text { did not work through arbritase, if it did not work through the } \\
\text { Religious Court. }\end{array}$ \\
\hline $\begin{array}{l}\text { Waqf Dispute } \\
\text { Institution }\end{array}$ & Polic \\
\hline
\end{tabular}

\subsection{Waqf Law in Malaysia}

Based on Malaysian history, it could be found out that the introduction and implementation of waqf began around $1800 \mathrm{AD}$, that was brought by Gujarati traders while spreading Islam in Malaysia. This could be proven by the existence of several mosques in Malaysia that were waqf-based, such as Hulu Mosque in Malacca and Sultan Abu Bakar Mosque in Johor. At that time, waqf had become a part of daily worship activities, the community was very enthusiastic or passionate about donating to waqf[11]. According to Othman (1986), the practice of waqf in Malaysia was believed to have lasted for eight centuries, since the presence of Arab Muslim traders who spreaded Islam in the Malay peninsula in the X century AD The legal framework for waqf in Malaysia was based on the framework of Islamic law, as the applied law in Malaysia[12].

Malaysia's federal constitution mandated that Islamic religious code including waqf in states that had sultan (or other equivalent title) was governed by state regulations. Moreover, for states that did not have sultan, such as Sabah, Sarawak and Malacca, as well as federal territories such as Kuala Lumpur and Putrajaya, the regulation used Islamic religious law including management of waqf following the Administration of the Religion of Islam (Federal Territories) Act 1993[13].

The legal basis used as the guidelines in waqf law in Malaysia, as stated by Zubaidah \& Hilal [13], were the Federal Constitution 1957 (section 3.4.1, article 3), National Land Code 1965 (NLC), Administration of Islamic Law (Federal Territories) (Act 505 of 1993), Selangor Wakaf Enactment (No. 7 of 1999), Trustee Act 1949 (Act 208), Malacca Wakaf Enactment 
2005, Negeri Sembilan Wakaf Enactment 2005, other Islamic law regulations issued by each state, Specific Relief Act 1950, Contracts Act 1950.

Waqf law in Malaysia were set by the government in each state. This was because 9 of 13 states in Malaysia were sultanates led by the sultan as head of local government. In states that was not led by a sultan, such as; Sabah, Sarawak and Malacca, as well as federal territories such as Kuala Lumpur and Putrajaya, the regulation of waqf as well as other Islamic religious regulations was under the federal government. Thus, waqf law might be different from one state to another state [14].

In Malaysia, perwakafan used main teaching Shafi'i mazhab, because this mazhab was adopted by the first Islamic ulama (Muslim scholar) who spreaded Islam in Asian including Malaysia and the community who accepted it so that the teachings of shafi'i mazhab could be developed. In addition, Shafi'i's ideology was recognized as fiqh mazhab that represented the intersection point of thought between textualist traditions and had become a vital elan for the existence of waqf law in Malaysia[15].

In Malaysia, the implementation of waqf regulation was under the authority of Indonesian Council of Religious Scholars (MUI) as the enforcer of waqf law in concerned states. Then, each MUI had the authority to validate, regulate, supervise and manage consumptive waqf within the states. The Majlis had an Advisory Board and Waqf Asset Management Committee. The Advisory Board consisted of individuals with experience in the field of Islamic law appointed by the Majlis with the state Mufti, the secretary of MUI, the state director for Agrarian Affairs and state officials in the field of legal consultant being permanent members. The other members consisted of state finance officials, academics and practitioners in professions related to Islamic law, property management and financial management [2].

Based on the explanation above, it could be understood that legal framework that was enacted in Malaysia tended to be different among the states, everything that regulated waqf was regulated independently by each state government [16]. Different legal framework and management practices for waqf affected the efficiency of planning and distribution between states. This gave impact in the practice of waqf in Malaysia until today, mostly of it was only limited to land. Even though, in its management it was bound by the provisions required by waqif. In addition, there were still many waqf lands that were managed besides the Religious Council, the nazhir was not economists and had no management background, so that some of waqf in Malaysian state were less productive and less economical [11].

In addition, it also gave impact on the settlement of waqf disputes that was different depended on the interpretation of the institution of law maker. In various cases regarding waqf in Malaysia, there were disparities in opinions and interpretations between legal entities that had the competence or authority to make and interpret the regulations and waqf manager. One of interpretations that had been decided by the State Legislative Institution was automatically imperfect when the the Council (Parliament), whose authority was higher, decided otherwise. As the response of this case, Hokker considered that ideally the Court Council should not interfere the affairs under the authority of the Low Court too far, because it would assume a dictatorial system in regulating waqf. Furthermore, he emphasized and noted that in this field, changes or at least additional regulations need to be added in Malaysia[17].

In addition, the management of waqf in Malaysia that was generally under the authority of MUI was considered as insignificantly contributed to the welfare of the community, both economically and socially. This was caused by many people who gave waqf but were not in accordance with the regulation of waqf and the lack similarity in the regulation of waqf, so that the differences in interpretation and guidelines for the implementation of waqf happened. 
This situation had encouraged Malaysian people to propose to the government to establish waqf institutions that managed waqf centrally, not under the authority of the state MUI, so that it could encourage the growth of waqf assets in Malaysia.

On the issue of waqf dispute settlement, Malaysian people mostly used non-litigation process, through deliberation and mediation. This was due to the factor of judicial power in handling waqf disputes. Authorized court institution to settle waqf disputes was the General Court, not the Religious Court. Although waqf system in Malaysia was centered on the MUI, however, many waqf disputes actually ended up in general courts, not Islamic courts, where the general court was higher than Islamic court. This caused many differences in Islamic cases that should only be settled in Islamic courts. Ironically, the competence of judges in the general court had low mastery in Islamic law [18], even though the case of waqf must be a Muslim case related to Islamic law or sharia.

Based on the explanation above, it could be concluded about waqf legal policy in Malaysia through the following table :

Tab 2. Waqf Law in Malaysia

\begin{tabular}{|c|c|}
\hline Waqf Law in Malaysia & Description \\
\hline The emergence history & $\begin{array}{l}1800 \text { AD, brought by Gujarati traders while spreading Islam in } \\
\text { Malaysia. }\end{array}$ \\
\hline Legal Basis & $\begin{array}{l}\text { Federal Constitution } 1957 \text { (section 3.4.1, article 3), National Land } \\
\text { Code } 1965 \text { (NLC), Administration of Islamic Law (Federal } \\
\text { Territories) (Act } 505 \text { of } 1993) \text {, Selangor Wakaf Enactment (No. } 7 \\
\text { of 1999), Trustee Act } 1949 \text { (Act 208), Malacca Wakaf Enactment } \\
\text { 2005, Negeri Sembilan Wakaf Enactment 2005, Specific Relief Act } \\
\text { 1950, Contracts Act } 1950 . \\
\text { Other Islamic laws that were issued by each state. }\end{array}$ \\
\hline Legal Mazhab & $\begin{array}{l}\text { It was different depended on state policy. Sabah, Sarawak and } \\
\text { Malacca, as well as federal territories such as Kuala Lumpur and } \\
\text { Putrajaya, Islamic regulations including the management of waqf } \\
\text { was based on absolute Syafi'i mazhab. In some other states, they } \\
\text { used non-absolute syafi'i mazhab, such as Hanafi mazhab. }\end{array}$ \\
\hline Waqf Legal Framework & $\begin{array}{l}\text { Each state was different, everything that regulated waqf was } \\
\text { regulated independently by each state government. }\end{array}$ \\
\hline Waqf Practice Implementer & $\begin{array}{l}\text { MUI had the authority to validate, regulate, supervise and manage } \\
\text { consumptive waqf within the state. MUI collaborated with the } \\
\text { Advisory Board and Waqf Asset Management Committee. The } \\
\text { Advisory Board consisted of individuals with experience in the } \\
\text { field of Islamic law that was appointed by Majlis with the state } \\
\text { Mufti, the secretary of MUI, the state director for Agrarian Affairs } \\
\text { and state officials in the field of legal consultant being permanent } \\
\text { members. }\end{array}$ \\
\hline Nazhir Coordinator & MUI \\
\hline The Use of Waqf Assets & $\begin{array}{l}\text { Sabah, Sarawak and Malacca, as well as federal territories such as } \\
\text { Kuala Lumpur and Putrajaya, their waqf assets were immovable } \\
\text { property, whose use for agriculture, plantations, rentals, places of } \\
\text { worship, places of education, and hospitals. Apart from these } \\
\text { states, waqf assets were used for economic value, such as; business, } \\
\text { property, stocks and investments. }\end{array}$ \\
\hline Waqf Disputes Settlement & $\begin{array}{l}\text { It used non-litigation process more. The authorized court to settle } \\
\text { waqf case was General Court. }\end{array}$ \\
\hline
\end{tabular}




\subsection{Comparative Study of Waqf Legal System between Indonesia and Malaysia}

A comparative study of waqf legal system between Indonesia and Malaysia was an attempt to describe or explain waqf law that was enacted in Indonesia and Malaysia, then a comparison between both of them. This was done to determine the characteristics of each country in enforcing the waqf law.

Based on the explanation above, it could be found out about waqf law that was enacted in Indonesia and Malaysia. When they were compared, it could be seen in the table as follows;

Tab 3. Comparison waqf legal system between Indonesia and Malaysia

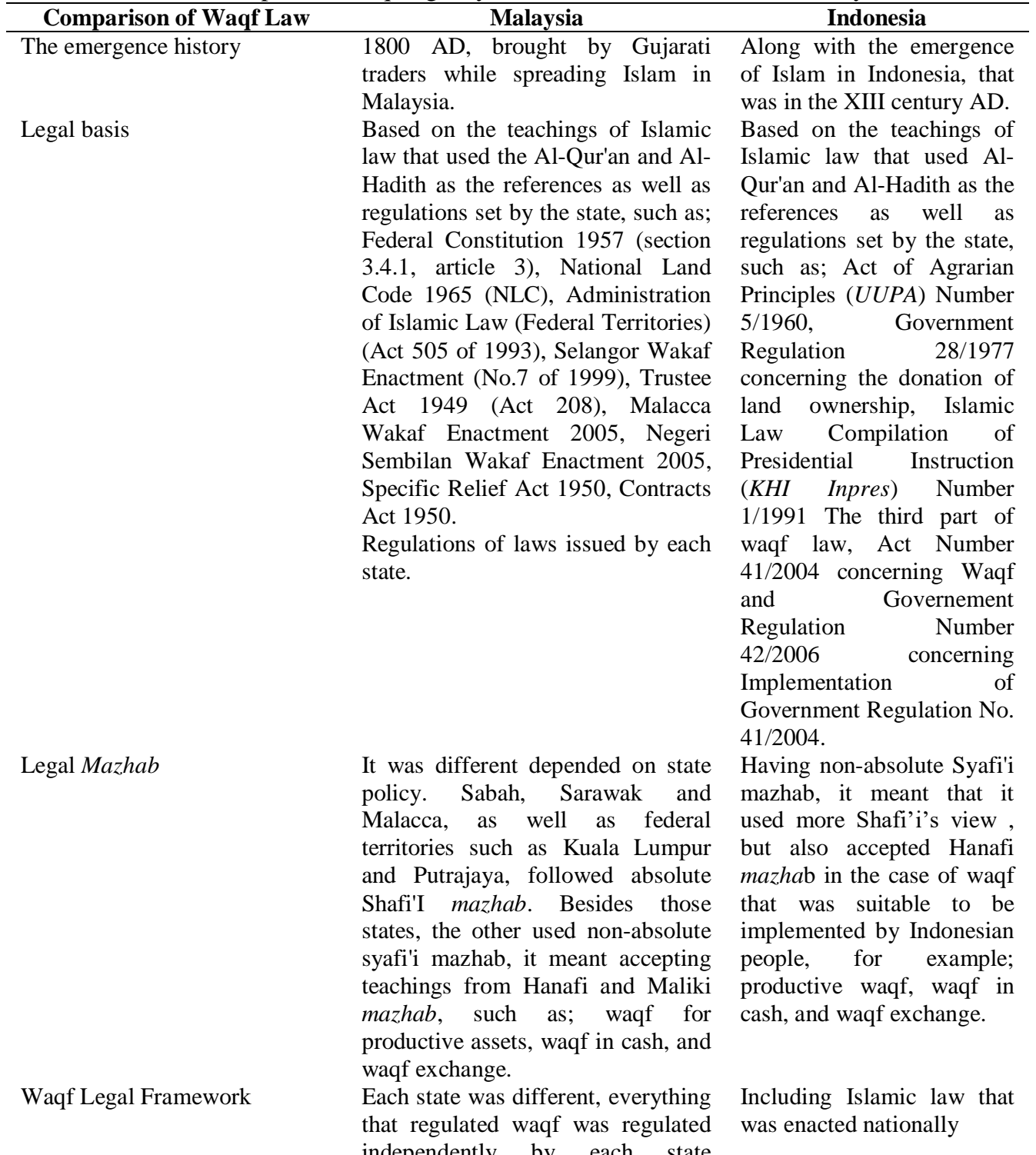


Waqf Practice Implementer

Nazhir Coordinator

The use of Waqf assets

Waqf

Settlement government.

MUI had the authority to validate, regulate, supervise and manage consumptive waqf within the state. MUI collaborated with the Advisory Board and the Waqf Asset Management Committee. The Advisory Board consisted of individuals with experience in the field of Islamic law appointed by the Majlis with the state Mufti, the secretary of MUI, the state director for Agrarian Affairs and state officials in the field of legal consultant being permanent members.

MUI (Indonesian Council of Religious Scholars/Majles Ulama Islam)

Sabah, Sarawak and Malacca, as well as federal territories such as Kuala Lumpur and Putrajaya, their waqf assets were immovable property, that were used for agriculture, plantations, rentals, places of worship, places of education, and hospitals. Besides these states, waqf assets were used for economic value, such as; business, property, stocks and investments.
Under the coordination of BWI and the Ministry of Religion through the District Ulama Council, that was called as Religious Affairs Office.
BWI collaborated with Nazhir who was from the element of community, such as; BKM (Mosque Welfare Agency), institutions, foundations, or community organizations, such as NU and Muhammadiyah to manage waqf assets according to community needs.

The use of waqf assets in the aspects of worship, then social, education, health, morals, public service facilities and the economy.

\footnotetext{
Disputes It used more non-litigation process. Through litigation and nonAuthorized court to settle waqf case litigation process. Authorized court was General Court. to settle waqf disputes was Religious Court.
}

Based on the table above, it could be analyzed that the similarity between waqf legal system in Indonesia and waqf legal system in Malaysia was their legal framework, where both of them used Islamic legal framework with non-absolute Syafi'i mazhab. Common difference was the form of government of Malaysia, that consisted of thirteen (13) states, tended to use different waqf legal systems, including the legal basis, the allocation of the waqf assets, mazhab of waqf legal teachings, and the use of the assets.

The states of Malaysia that used the teachings of absolute Syafi'i mazhab waqf law, such as; Sabah, Sarawak and Malacca, as well as federal territories such as Kuala Lumpur and 
Putrajaya. Syafi'i Mazhab taught that the assets that could be donated were only fixed assets/land, so it was easier for the people to give it, the state allowed credit waqf. Credit waqf was waqf by paying in installments or credit every month for the assets that had been donated in the form of immovable aasets, because they were expensive and was not able to pay it in cash. It caused rapid growth of waqf in Malaysia, because the state provided community services according to their capabilities without violating Islamic sharia.

The states under Sultan's rule, used the teachings of the waqf law of mazhab of Syafi'i, Hanafi and Syafi'i, that allowed movable assets of waqf, such as; waqf in cash, Marketable securities/sukuk, waqf obtained from rent, and others. The advantages of this waqf system were wakif could gave waqf in cash and according to his ability. The assets of movable assets of waqf could be managed through economic activities, for example; to provide capital for low-income entrepreneurs, for investment and its profits were used to help general welfare and improve living standards.

In every state of Malaysia, full authority of waqf belonged to Majlis Ugama Islam/Indonesian Council of Religious Scholars (MUI), however in 2008, Prime Minister Tun Abdullah Ahmad Badawi announced the formation of the Department of Waqf, Zakat and Haj (JAWHAR), whose duty was implementing the authority of federal government in waqf management affair. The establishment of JAWHAR was expected to provide development in the management of waqf in a more organized, systematic and effective manner. In carrying out his duty, JAWHAR as the executor of federal power in the field of waqf only played role as the coordinator of MUI in the states.

In context of the settlement of waqf disputes, Malaysians mostly settled their disputes through non-litigation process in the form of deliberation and mediation, and less used syari'ah arbritase process. This was because the use of waqf assets was more in the function of worship. However, in the states of Malaysia that used non-absolute Shafi'i mazhab, where the allocation of waqf assets was more based on economic value, they used waqf dispute settlement through sharia arbritase using Islamic financial system. The settlement of waqf disputes using litigation that was through the Court Institution therefore Malaysia had appointed a General Court or Conventional Court to settle waqf disputes that included in the realm of Islamic economics.

In contrast with Indonesia, since the issuance of Waqf Law Number 41/2004 the enactment of the waqf legal system was constitutionally equal for all Indonesian people. There were several legal innovations regulated in Waqf Law, for example; Waqf might be movable assets as long as the principal or original assets were retained and their use was developed, waqf might has limited time as long as its use was permanent, the management of waqf assets that was professional, certification of waqf (for land). However, the waqf management institution (BWI) established by the Indonesian government had been stagnant so far, because the government's political will had not fully supported the enforcement of waqf law in Indonesia. In addition, the authority to implement waqf law that was held by the Ministry of Religion had also experienced many legal and social problems, for example; the legality of waqf, protection and salvation of waqf assets, misunderstandings among waqf, infaq and shadaqah, management of waqf, and education of waqf for the community.

The comparison of waqf law between Malaysia and Indonesia could give inspiration for the development of waqf in Indonesia, especially in the management of waqf assets in a professional, accountable and transparent manner. In addition, in Malaysia, there had been a mindset that waqf was a job that contained the mandate of the world and the hereafter. Therefore the institution that had the authority to provide waqf services and manage the increasing number of waqf assets was the Ministry of Waqf, Zakat and Hajj. 


\section{Conclusion and Suggestion}

Based on the explanation above, it can be concluded that the implementation of waqf law between Indonesia and Malaysia has similarities and differences as their own characteristics which are adjusted to the typology of the community. The form of government of Indonesia and Malaysia is different, therefore the legal system is also different. The point of similarity of waqf law between the two countries is Islamic legal framework of non-absolute Shafi'I mazhab. However, this is only implemented in certain states.

The suggestion that deserves to be provided is by comparing the enactment of the waqf law between Indonesia and Malaysia; it will provide inspiration and motivation for the development of Indonesian waqf in a professional manner, both through its legal culture, guidelines and law enforcement.

\section{References}

[1] M. I. A. bin M. Al-Shaukani, Mustafa Al-Bab Al-Halan, Vol. III. Kairo: Nayl Al-Awtar.

[2] Tuti A Najib dan Ridwan Al-Makassary (ed), Ed., Wakaf, Tuhan, dan Agenda Kemanusiaan. Jakarta: CSCR UIN Syarif Hidayatullah, 2006.

[3] M. A. Mahdiy, Sistem Pengelolaan Wakaf dalam Aplikasinya Masa Kini, Contoh-Contoh Terpilih dari Praktek Wakaf di berbagai Negara dan Masyarakat Islam. Jeddah: Bank Pembangunan Islam, 2001.

[4] R. Djatmiko, Wakaf Tanah. Surabaya: Al Ikhlas, 1962.

[5] M. A. A. al Kabisi, Waqf Law. Jakarta: IIMAaN Press, 2004.

[6] S. A. B. bin S. Muhammad, I'anah al-Thalibin, Juz III. Beirut: Daar al-Kutub al-Ilmiah.

[7] M. Y.; A. R. L. Lubis, Hukum Pendaftaran Tanah. Bandung: Mandar Maju, 2008.

[8] U. Santoso, Hukum Agraria dan Hak-hak atas Tanah. Jakarta: Prenada Media, 2005.

[9] B. Arifin, Pelembagaan Hukum Islam di Indonesia: Akar Sejarah, Hambatan dan Prospeknya. Jakarta: Gema Insani Press, 1966.

[10] A. G. Anshori, Hukum dan Praktek Perwakafan di Indonesia. Yogyakarta: Pilar Media, 2005.

[11] S. Harahap, Pedoman Pengelolaan dan Perkembangan Wakaf. Jakarta: Direktorat Jendral Bimbingan Masyarakat Islam, Direktorat Pemberdayaan Wakaf, Kementrian Agama Republik Indonesia, 2006.

[12] F. H. Othman, Islam dan Kemajuan Masyarakat "Islam Menyeru Ke Arah Kebajikan." Kuala Lumpur: Institut Kefahaman Malaysia, 1996.

[13] Zubaidah; Hilal, Bank Indonesia, Wakaf: Pengaturan dan Tata Kelola yang Efektif. Departemen Ekonomi dan Syariah bekerjasama dengan Departemen Ekonomi Syariah Fakultas Ekonomi dan Bisnis Syariah, Unair, 2016.

[14] M. Cizaska, A History Of Philanthropic Foundation: The Islamic Of World From The Seventh Century Of The Present. Istambul: Bogazici University Press, 2000.

[15] S. H. Amin, Islamic Law and Its Implication for Modern World. Scotland: Royston Ltd, 1989.

[16] T. A.; R. A. M. Najib, "Management and development of Awqaf Properties," in Proceeding of Management and development of Awqaf Properties, 1987, p. 259.

[17] M.B.Hoker, Undang- undang Islam di Asia Tenggara. Kuala Lumpur: Dewan Bahasa dan Pustaka, 1991.

[18] A.; R. H. Triyanta, "Penyelesaian Sengketa Bisnis Keuangan Islam Melalui Pengadilan di Malaysia dan Relevansinya dengan Indonesia,” J. Huk., vol. 15, no. 2, p. 2009, 2008. 